\title{
Rufinamide Kullanımı Sonrası Gelişen Akut Pankreatit: Olgu Sunumu
}

\section{Acute Pancreatitis due to the use of Rufinamide}

\section{Oya Balcl', Taner Sezer ${ }^{2}$}

${ }^{1}$ Keçiören Eğitim ve Araştırma Hastanesi Çocuk Gastroenteroloji Hepatoloji ve Beslenme Bölümü, Ankara

${ }^{2}$ Başkent Üniversitesi Tıp Fakültesi Çocuk Nöroloji BD, Ankara

\section{ÖZET}

Akut pankreatit pankreasın akut inflamasyonudur. Hastalığın hafif bir şekli olan ödematöz pankreatitten ağır bir klinikle seyreden nekrotizan pankreatite kadar farklı şiddetlerde patolojik değişikliklerle seyredebilir. Bu nedenle hastalığın prognozu da oldukça değişkendir. Yeni geçirilmiş enfeksiyonlar, ilaç kullanımı, travma ve altta yatan hastalıkların üzerinde durulması akut pankreatit tanısını kolaylaştırmaktadır. Bu olgu sunumunda rufinamid tedavisine bağlı akut pankreatit gelişen bir olgu literatürde ilk olarak bildirilmiştir.

Anahtar kelimeler: Akut pankreatit, rufinamid, antiepileptik ilaç

\section{ABSTRACT}

Acute pancreatitis is a acute inflammatory process involving the pancreas. The incidence of acute pancreatitis during childhood has been estimated to be 3.6-13.2/100.000. The common causes of acute pancreatitis in childhood are infections, choledekolithiasis, abdominal trauma, and drugs. Drug induced pancreatitis accounts for approximately $13-25 \%$ of acute pancreatitis cases in childhood. Among different drugs, anticonvulsants; most commonly valproic asit, carbamezepine, ethosuximide and diphenylhydantoin have been implicated to cause acute pancreatitis. To our best knowledge, this case is the first report in the pertinent literature that relates rufinamide and acute pancreatitis.

Keywords: Acute pancreatitis, rufinamide, antiepileptic drug
Corresponding Author: Oya Balcı

Address: Keçiören Eğitim ve Araştırma Hastanesi Çocuk Gastroenteroloji Hepatoloji ve Beslenme Bölümü, Keçiören, Ankara E-mail: oyabalci@yahoo.com
Başvuru Tarihi/Received: 24-03-2016

Kabul Tarihi/Accepted: 29-03-2016 


\section{GiRiş}

Akut pankreatit pankreasın akut inflamasyo-nudur. Çocukluk çağında akut pankreatit insi-dansı 3,6-13,2/100000 arasında değişmektedir (1). Akut pankreatit genellikle enfeksiyonlar, ko-ledokolitiasis, travmalar ve ilaçlara bağlı gelişir. İlaçlara bağlı akut pankreatit tüm akut pankreatitlerin \%13-25'inde gözlenmektedir. Antiepilep-tik ilaçlardan en sık valproik asit ve daha nadiren karbamazepin, ethosüksimid ve difenilhidantoi-ne bağlı $A P$ bildirilmiştir (2). Bu olgu sunumunda rufinamid tedavisine bağlı akut pankreatit geli-şen bir olgu literatürde ilk olarak bildirilmiştir.

\section{OLGU SUNUMU}

Yedi yaşında erkek çocuğu, acil servise ani gelişen karın ağrısı nedeniyle getirildi. Öyküsün-den anne baba arasında 1 . derece akraba evli-liği olduğu ve ailenin ilk bebeği olarak $3400 \mathrm{gr}$ ağırlığında zamanında doğduğu, epilepsi ve hafif mental retardasyon tanılarıyla takip edildiği öğrenildi. Epileptik nöbetlerin 2 yaşında başladığı, beyin manyetik rezonans görüntüleme ve me-tabolik testlerinin normal olduğu, EEG bulguları ve klinik bulgular ile Lennox-Gastaut Sendromu tanısı konulduğu öğrenildi. Hastanın karbamazepin ve levetirasetam tedavileri altında nöbetleri devam ettiği için tedavisine 4 gün önce rufina-mid tedavisi eklendiği öğrenildi. Travma öyküsü yoktu. Soygeçmişinde özellik yoktu.

Hastanın başvuru anında ateşi nabzı 70 / daki-ka, solunum sayısı 18/dakika, vücut ısısı: $37.2^{\circ} \mathrm{C}$ (aksiller) idi. Fizik muayenede halsiz görünüm ve karında yaygın hassasiyeti mevcuttu, diğer sistem muayeneleri normaldi. Laboratuvar in-celemelerinde; tam kan sayımı, CRP, kan şekeri, kreatinin, AST, ALT, GGT, albumin, elektrolitleri normal olan hastanın serum amilazı $1830 \mathrm{U} / \mathrm{L}$ ve lipazı
$1240 \mathrm{U} / \mathrm{L}$ idi. İdrar tetkiki normaldi. Hastanın oral alımı durduruldu, i.v hidrasyon tedavisi verildi. İzlemde karın ağrısında azalma olmadı. İzlemde serum amilaz ve lipaz değerlerinde düşme gözlenmedi. Ayakta direkt batın grafisi ve abdomen USG normal olan hastanın bilgisayarlı karın tomografisinde pankreasın ödemli görü-nümde olduğu, pankreatitle uyumlu olduğu rapor edildi. Olgumuzda etiyolojiye yönelik olarak gönderilen trigliserid düzeyleri, viral serolojileri (Mycoplasma IgM, Kabakulak IgM, Rubeola IgM dahil) ve otoimmun antikorlardan ANA, ASMA, Ig G düzeyleri normal saptandı.IgG4 bakılama-dı. Bu bulgularla rufinamide bağlı AP olabileceği düşünülen hastanın rufinamid tedavisi kesilerek klonazepam tedavisi başlandı. Takiplerinde ilacın kesilmesinden 2 gün sonra hastanın şikayetleri düzeldi,oral beslenmeye başlanıldı, amilaz de-ğerleri normale döndü ve ilaç kesilmesinden 7 gün sonra taburcu edildi.

\section{TARTIŞMA}

Akut pankreatit ortak safra kanalı taşı, ilaçlar, sistemik hastalıklar, travma, metabolik hastalık-lar ve herediter nedenlere bağlı olabilmektedir $(1,2)$. Illaca bağlı pankreatit çocuk hastalarda ya-pılan bir çalışmada \%25,6 oranında tespit edil-miştir. En sık etken olan ilaçlar valproik asit ve steroidler,meselamin iken ilaca bağlı pankreatite en sık eşlik eden hastalıklar epilepsi, akut lenfo-sitik lösemi, crohn hastalığıdır. İlaca bağlı pank-reatitte daha az sıklıktaki görülen diğer ilaçlar ise trimeoprimsülfametaksazol, 6-merkaptopurin, asparaginaz, azotioprin, vincristin, furosemid, pentamidin, hidroklorotiyazidtir (2).

Çocukluk çağında ilaca bağlı pankreatitlerden en sık sorumlu ilaç steroidlerdir. Antiepileptikler 2. sırada olup en sık pankreatit yapan anti-epileptik valproik asittir. Rufinamid son yıllarda geliştirilen ve çocukluk çağında direçli epilepsilerde, 4 yaşın üzerinde kullanılması önerilen bir antiepileptiktir (3). Dirençli epilepsi tansıyla takipli ve diğer antiepileptik ilaçlara rufinamid ek- 
lenen 300 çocuğun retrospektif olarak incelendi-ği bir çalışmada hastaların 19'unda $(\% 26,3)$ yan etki saptanmıştır. Bu çalışmada en sık gözlenen yan etkiler uykusuzluk (\% $26,6)$, kusma (\%21,5), duygu durum değişikliği $(\% 16,5)$ ve iştah kaybı $(\% 11,4)$ olarak bildirilmiştir (4). Olgumuz bugüne kadar rufinamide bağı akut pankreatit gelişen ilk vakadır. Olgumuzda, rufinamid tedavisinden 4 gün sonra akut pankreatit tablosu gelişmesi, rufinamid tedavinin kesilmesinden sonra semptomların ve laboratuvar değerlerindeki düzelme nedeniyle akut pankreatitin rufinamide bağlı ge-liştiğini düşünüyoruz.

Tanıda gecikmeler akut pankreatitin mortalite ve morbiditesini yükselteceğinden ilaçlara bağlı akut pankreatitin akılda tutulması ve şüpheli olgularda ilaç tedavisinin hemen kesilmesi önemlidir. Sonuç olarak olgumuzu akut pankreatitin, antiepileptik ilaçlardan rufinamide bağlı da geli-şebileceğini vurgulamak için sunduk.

\section{KAYNAKLAR}

1. Vinklerová I, Procházka M, Procházka V, Urbánek K. Incidence, severity, and etiology of drug-induced acute pancreatitis. Dig Dis Sci 2010;55:2977-81.

2. Bai HX, Ma MH, Orabi Al, Park A, et al. Novel characterization of drug-associated pancreatitis in children. J Pediatr Gastroenterol Nutr 2011;5:423-8.

3. Kluger G, Kurlemann G, Haberlandt E, et al. Effective- ness and tolerability of rufinamide in children and adults with refractory epilepsy: first European experience. Epilepsy Behav 2009;14:491-5.

4. Thome-Souza S, Kadish NE, Ramgopal S, et al. Safety and retention rate of rufinamide in 300 patients: a single pediatric epilepsy center experience. Epilepsia 2014;55:1235-44 